\title{
FOAMING AND EMULSIFYING CAPACITY, FOAM AND EMULSION STABILITY OF PROTEINS OF PORCINE BLOOD: DETERMINATION AT DIFFERENT VALUES OF pH AND CONCENTRATIONS
}

\section{CAPACIDADE DE FORMAÇÃO E ESTABILIDADE DA EMULSÃO E CAPACIDADE DE FORMAÇ̃̃O E ESTABILIDADE DA ESPUMA DE PROTEÍNAS DE SANGUE SUİNO: DETERMINAÇÃO EM DIFERENTES pHS E CONCENTRAÇÕES}

\author{
Aniela Pinto Kempka ${ }^{1}$; Francisco José Horvath ${ }^{1}$, Pâmela Fagundes ${ }^{1}$, Rosa Cristina Prestes ${ }^{2}$ \\ ${ }^{1}$ Universidade do Estado de Santa Catarina - UDESC - Pinhalzinho - Brasil aniela.kempka@ udesc.br \\ ${ }^{3}$ Universidade Federal de Santa Maria - UFSM- Santa Maria - Brasil
}

\begin{abstract}
The present study aimed to evaluate the surface properties of the plasma and hemoglobin in different values of $\mathrm{pH}$ and concentrations. The two samples showed similar profiles foaming capacity in the $\mathrm{pH}$ range tested (3, 5, 7, 8 and 11) but with different values and distant from neutrality. The plasma showed the lower foaming capacity and foam stability for all $\mathrm{pH}$ values. The values of emulsion stability were higher to the plasma in all $\mathrm{pH}$, and all showed values are equal statistically. Observed for the plasma, the higher foaming capacity was for concentration of $0.50 \%$, higher and statistically different from the others concentrations. Decrease in the concentration of sample to $0.1 \%$ and $0.25 \%$, led to a reduction in foam stability using plasma and hemoglobin. For the two samples, from the concentration of $1.5 \%$, the values of emulsifying activity were similar. Statistically, the values obtained at concentrations of $1.5 \%$ and $2.5 \%$ were statistically equal to each other and different from the values obtained for 3.5 and $4.5 \%$. The emulsion formed using plasma and hemoglobin was more stable from the concentration of $3.5 \%$ and $1.5 \%$, respectively. Regarding the surface properties, the proteins were shown to be promising for use in food.
\end{abstract}

Keywords: plasma, hemoglobin, foam, emulsion, $\mathrm{pH}$, concentration.

\section{Introduction}

Animal blood is potentially an untapped source of drugs and value-added food production. Porcine blood is rich in proteins but is usually discarded which may cause environmental contamination. Recovering porcine blood and converting it to highly valued economic products is highly desired (YU et al., 2006). The utilisation of porcine serum protein is limited (LIU et al., 2010). 
Besides nutritional quality, functional properties of proteins are also important for food product formulations. The importance of these properties varies with the type of food products in which the protein is used (JAMDAR et al., 2010). Functional properties can be defined as the overall physicchemical behavior of performance of proteins in food systems during processing, storage and consumption (HMIDET et al., 2011). The study of the functional properties it is essentially important in determining the potential application of protein in products, allowing also defining the use of the proteins as substitute or supplementing in traditional foods in the form of crude protein (SILVA, 2007). Emulsifying and foaming properties are important functional properties and are termed as surface properties.

The foam stability is important for foods such as ice cream, Chantilly, mousses and marshmallow, with respect to shelf-life and appearance of the product, and must be maintained when subject to process variations such as heating, mixing and cutting (FOEGEDING et al., 2006). In general, proteins that exhibit low foaming capacity show good stability and vice versa. At $\mathrm{pH}$ different from the isoelectric point of the protein, the foamability is usually satisfactory, but the foam stability is low (DAMODARAN et al., 2010).

Emulsions are defined as dispersions of two (or more) immiscible liquids which are inherently thermodynamically unstable and tend to phase separate overtime via creaming, flocculation and/or coalescence. Emulsion stability is highly dependent upon liquid droplet size and distribution, emulsion processing conditions (i.e., homogenization rates), protein characteristics (i.e., size, conformation, surface reactivity, concentration and solubility), solvent conditions (i.e., $\mathrm{pH}$, salts and temperature), phase volume ratio and continuous phase viscosity (AVRAMENKO et al., 2013).

Therefore, this study aimed to determine the surface properties of porcine plasma and hemoglobin for possible application in food formulation. The surface properties determined was: foaming capacity, foam stability, emulsifying activity and emulsion stability in different values of $\mathrm{pH}$ and different values of concentration.

\section{Material and Methods}

The experiments were performed at the Laboratory of Bioprocess of the Department of Food Engineering, State University of Santa Catarina, Pinhalzinho-SC, Brazil. The plasma (76.12\% of the protein) and hemoglobin (89.59\% of the protein), dehydrated, were provided by APC do Brasil Chapecó-SC- Brazil. 


\subsection{Foaming capacity and foam stability of the plasma and hemoglobin in different pHs and concentrations}

Foaming capacity and foam stability of plasma and hemoglobin were determined according to the method of Liu et al. (2010). To determine the foaming capacity at different pH was added $0.5 \%(\mathrm{w} / \mathrm{v})$ of protein (plasma or hemoglobin) in $20 \mathrm{ml}$ of buffer ( $\mathrm{pH} \mathrm{3,5,7,8}$ and 11). To determine the foaming capacity in different concentrations was used a fixed value buffer of $\mathrm{pH}$, varying the concentrations of plasma or hemoglobin, as follows: $0.10 \%, 0.25 \%, 0.50 \%, 0.75 \%$ and $1.00 \%(\mathrm{w} / \mathrm{v})$. After, the solution was homogenized using a mixer for 2 minutes and subsequently transferred to a beaker of $25 \mathrm{ml}$ and the total volume read off after 30 seconds. The foaming capacity was calculated according to the Eq. 1:

$$
\text { Foaming capacity }(\%)=\left(\frac{A \cdot B}{B}\right) \times 100
$$

Where A is the volume after whipping (ml); B is the volume before whipping (ml).

The foam stability was determined by using the sample obtained in the foaming capacity. The whipped sample was allowed to stand at $20^{\circ} \mathrm{C}$ for 3 minutes and the volume of whipped sample was then recorded. Foaming stability was calculated according to the Eq. 2 (LIU et al., 2010):

$$
\text { Foam stability }(\%)=\left(\frac{A-B}{B}\right) \times 100
$$

Where $\mathrm{A}$ is the volume after standing $(\mathrm{ml})$; B is the volume before whipping $(\mathrm{ml})$.

\subsection{Emulsifying activity and emulsion stability of the plasma and hemoglobin in different pHs and concentrations}

The emulsifying activity was determined by the method of Wang and Kinsella (1976), with modifications. For determinations different $\mathrm{pH}$, was used protein suspensions at $3.5 \%(\mathrm{w} / \mathrm{v})$ in buffer 3, 5, 7, 8 and 11. To determine the emulsifying activity in different concentrations was used a fixed value buffer of $\mathrm{pH}$, varying the concentrations of plasma or hemoglobin, as follows: $0.5 \%$, $1.5 \%, 2.5 \%, 3.5 \%$ and $4.5 \%(\mathrm{w} / \mathrm{v})$. To verify the emulsifying activity, $20 \mathrm{ml}$ of maize oil was added to $20 \mathrm{ml}$ of suspension protein and subsequently stirred with domestic mixer for 1 minute. The emulsion formed was divided into tubes and centrifuged at 4,000 rpm for 6 minutes. The emulsifying activity was determined as the percentage of the emulsified layer that remained after centrifugation, and the percentage calculation performed using Eq.3:

$$
\text { Emulsifying activity }(\%)=\frac{A}{\mathrm{E}} \times 100
$$

Where A is the mass of the emulsified layer $(\mathrm{g})$ and B is the weight of sample $(\mathrm{g})$. 
The emulsion stability was determined by using the sample obtained in the emulsifying activity. To verify the emulsion stability, made up heating the emulsion in a water bath at $80^{\circ} \mathrm{C}$ for 30 minutes, followed by cooling to $15^{\circ} \mathrm{C}$ and centrifugation at $4,000 \mathrm{rpm}$ for 6 minutes. The emulsion stability was calculated as the percentage of the emulsified layer that remained after the heat treatment, using Eq. 4 (WANG and KINSELLA, 1976).

$$
\text { Emulsion stability }(\%)=\frac{A}{B} \times 100
$$

Where A is the mass of the emulsified layer $(\mathrm{g})$ and B is the weight of sample $(\mathrm{g})$.

\subsection{Statistical analysis}

Data were analyzed using the Statistica ${ }^{\circledR} 10.0$ (STATSOFT Inc.). Significant differences $(\mathrm{p}<0.05)$ between means were identified using Tukey procedures. All the experiments were carried out in triplicate.

\section{Results and Discussion}

\subsection{Surface properties of porcine plasma and hemoglobin in different $\mathrm{pH}$ values}

In Figure 1 are shown the profiles for the percentage of foaming capacity (a) and percentage of foam stability of plasma and hemoglobin samples at different $\mathrm{pH}$ (maintained constant the concentration of the sample in $0.5 \%$ ).

Figure 1 - Profiles of the Foaming Capacity (a) and Foam Stability (b) at different pH values for plasma (ㅁ--) and hemoglobin $(-\infty)$

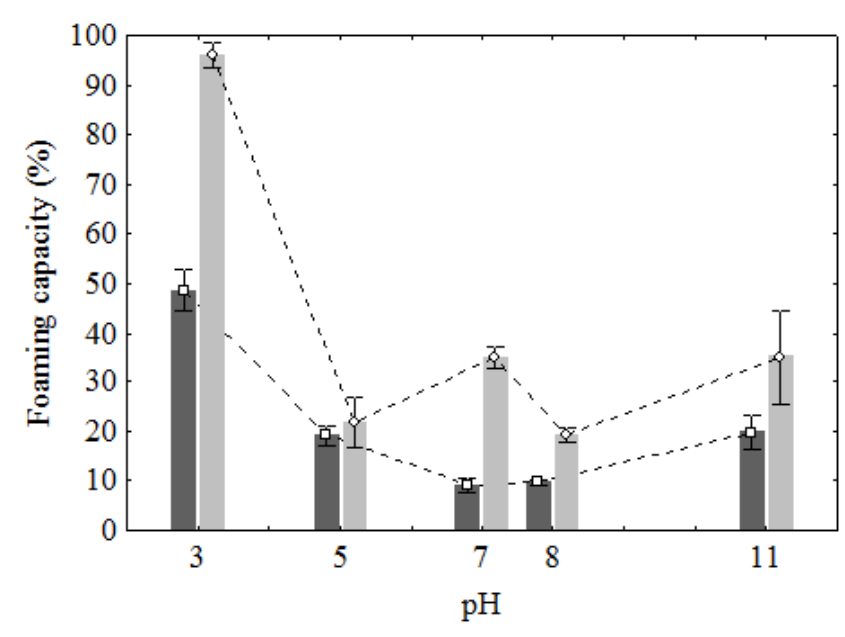

(a)

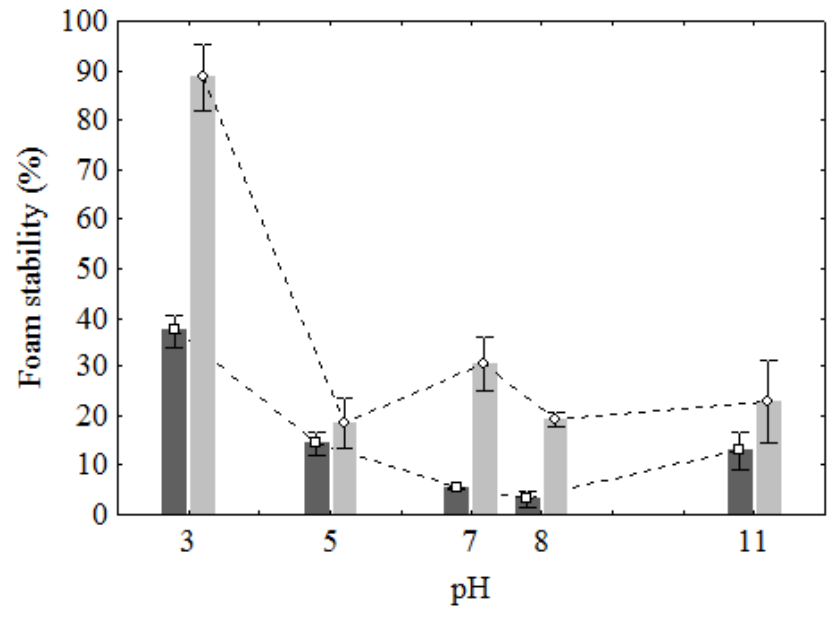

(b)

In Figure 1a, it is verified that the two samples showed different profiles to foaming capacity. The plasma showed lower foaming capacity for all tested $\mathrm{pH}$ compared with hemoglobin in addition 
to higher foaming capacity in the farthest $\mathrm{pH}$ of neutrality. The hemoglobin, although had a higher to foaming capacity at $\mathrm{pH} 3$, also showed similar values between them at $\mathrm{pH} 7$ and 11 . In Figure $1 \mathrm{~b}$ are shown the results of the foam stability to plasma and hemoglobin at different $\mathrm{pH}$ values. The foaming stability is related to the ability to remain stable front of gravitational or mechanical efforts, unlike the foaming capacity, which is characterized as the interfacial area that can be created by protein (FENNEMA, 2000).

Table 1 shows the mean of the results, the standard deviation and the Tukey test for the foaming capacity and foam stability of plasma and hemoglobin at different $\mathrm{pH}$ values.

Table 1- Mean of the results, the standard deviation and the Tukey test for the foaming capacity ad foam stability of plasma and hemoglobin at different $\mathrm{pH}$ values

\begin{tabular}{ccc|cc}
\hline $\mathrm{pH}$ & \multicolumn{2}{c|}{ Foaming capacity (\%) } & \multicolumn{2}{c}{ Foam stability (\%) } \\
& Plasma & Hemoglobin & Plasma & Hemoglobin \\
\hline 3 & $48.73^{\mathrm{aA}} \pm 2.94$ & $96.06^{\mathrm{aB}} \pm 1.79$ & $37.18^{\mathrm{aA}} \pm 2.65$ & $88.67^{\mathrm{aB}} \pm 5.32$ \\
5 & $19.16^{\mathrm{bA}} \pm 1.61$ & $21.73^{\mathrm{cA}} \pm 3.49$ & $14.39^{\mathrm{bA}} \pm 1.81$ & $18.40^{\mathrm{bA}} \pm 3.98$ \\
7 & $9.16^{\mathrm{cA}} \pm 1.24$ & $34.93^{\mathrm{bB}} \pm 1.80$ & $5.39^{\mathrm{cA}} \pm 0.16$ & $30.46^{\mathrm{bb}} \pm 4.33$ \\
8 & $9.70^{\mathrm{cA}} \pm 0.40$ & $19.25^{\mathrm{cB}} \pm 1.25$ & $3.15^{\mathrm{cA}} \pm 1.23$ & $19.25^{\mathrm{bB}} \pm 1.25$ \\
11 & $19.77^{\mathrm{bA}} \pm 2.75$ & $35.00^{\mathrm{bB}} \pm 7.02$ & $12.96^{\mathrm{bA}} \pm 3.14$ & $22.90^{\mathrm{bA}} \pm 6.61$ \\
\hline
\end{tabular}

Means \pm standard deviation followed by different lowercase letters, in the column, are different at the $95 \%$ level of confidence. Means \pm standard deviation followed by different uppercase letters, in the lines and for the same property, are different at the $95 \%$ level of confidence.

Both for the plasma as for hemoglobin, the highest values of foaming capacity was at $\mathrm{pH} 3$, values that differ statistically $(\mathrm{p}<0.05)$ by Tukey test, of all the other values this surface property for the same sample. The Tukey test showed that under the conditions of $\mathrm{pH} 5$ and 11, the results for the porcine plasma was statistically equal ( $\mathrm{p}>0.05)$. The same occurred for the samples of $\mathrm{pH} 7$ and 8 , statistically equal on a confidence interval of $95 \%$. For hemoglobin, the values of foaming capacity was statistically equal ( $\mathrm{p}>0.05$ ) between samples at $\mathrm{pH} 5$ and 8 and between samples at $\mathrm{pH}$ 7 and 11.

Although the two samples have had ample difference in results of means of the capacity foaming, they indicate a higher affinity of the proteins to form foam with the medium at $\mathrm{pH}$ 3. At pHs distant from the isoelectric point, the foaming capacity of a protein is satisfactory (FENNEMA, 2000). Jamdar et al. (2010) has lower results using peanut as a source of protein for the foaming, reaching about $40 \%$ of foaming using crude protein. Opposite results were found by Batistutti et al. (2007) with isolated guava seed protein and determined its functional properties, finding that a higher foaming capacity occurred at alkaline $\mathrm{pH}$ and at low with acidic pH. Silva et al. (2012) 
showed $62 \%$ of the foaming capacity using protein isolated from rice bran. Prentice-Hernández et al. (2009) achieved $13.1 \%$ of capacity foaming for protein hydrolysate of cabrinha.

The plasma showed lower foam stability at all $\mathrm{pH}$ values. In $\mathrm{pH} 3$, the foam stability to the plasma was $37.18 \%$, a value statistically different $(\mathrm{p}<0.05)$ of other values for foam stability

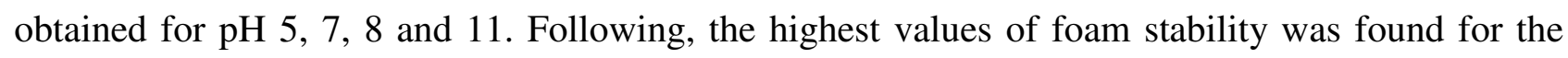
samples at pH 5 and pH11, statistically equal (p>0.05) by Tukey test. In pH 7 and 8, foams formed by the plasma had lower stability. Damodaran et al. (2010) reported that the stability of the foam is higher when the $\mathrm{pH}$ approaches the isoelectric point of the protein. This is because the intermolecular electrostatic attractions produced in these $\mathrm{pH}$ values are maximum and increase the rigidity and thickness of the adsorbed proteins at the interface between air and water, resulting in increased stability. Hmidet et al. (2011), studied the foam stability produced using the protein extracted of the Lula, and obtaining results of $55 \%$ and $43 \%$ of the foam stability for crude protein in $\mathrm{pH} 2$ and 4 . For hemoglobin the value obtained for foam stability at pH 3 shown the same pattern presented by foaming capacity, with different value statistically $(\mathrm{p}<0.05)$ than the other values of the foam stability obtained for other $\mathrm{pH}$ values. For other $\mathrm{pH}$ values $(5,7,8$ and 11) the results were statistically equal $(\mathrm{p}>0.05)$ by Tukey test.

The larger foaming stability of a protein can be found in $\mathrm{pH}$ of the isoelectric point. This is due to the fact that intermolecular electrostatic attractions produced in these $\mathrm{pH}$ values are great and increasing the thickness and stiffness of the protein adsorbed at the air/water interface, resulting in greater stability (ORDOÑEZ, 2005; DAMODARAN et al., 2010).

The profiles of the emulsifying activity and emulsion stability for plasma and hemoglobin at different $\mathrm{pH}$ values are shown in Figure 2.

Figure 2- Profiles of the Emulsifying Activity (a) and Emulsion Stability (b) at different pH values for plasma (and hemoglobin $(-\infty)$

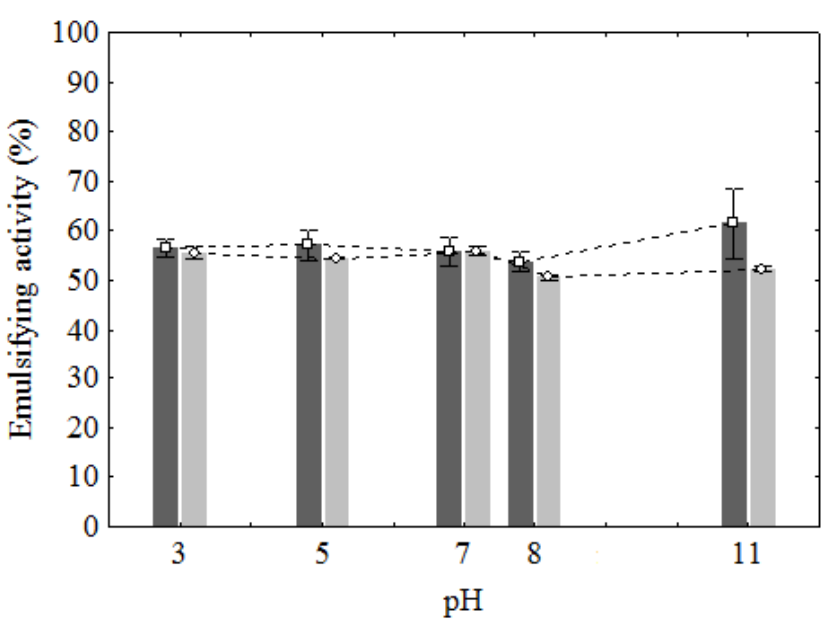

(a)

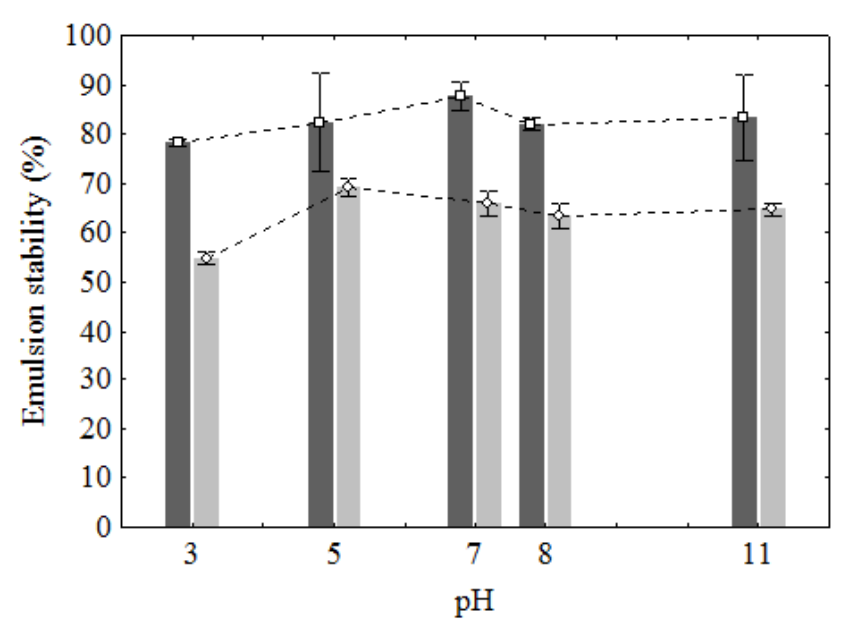

(b) 
Table 2 shows the mean of the results, the standard deviation and the Tukey test for the emulsifying activity and emulsion stability of plasma and hemoglobin at different $\mathrm{pH}$ values.

Table 2 - Mean of the results, the standard deviation and the Tukey test for the emulsifying activity and emulsion stability of plasma and hemoglobin at different $\mathrm{pH}$ values.

\begin{tabular}{|c|c|c|c|c|}
\hline \multirow{2}{*}{$\mathrm{pH}$} & \multicolumn{2}{|c|}{ Emulsifying activity (\%) } & \multicolumn{2}{|c|}{ Emulsion stability (\%) } \\
\hline & Plasma & Hemoglobin & Plasma & Hemoglobin \\
\hline 3 & $56.48^{\mathrm{aA}} \pm 1.44$ & $55.56^{\mathrm{aA}} \pm 0.95$ & $78.27^{\mathrm{aA}} \pm 0.48$ & $54.91^{\mathrm{cB}} \pm 0.99$ \\
\hline 5 & $57.18^{\mathrm{aA}} \pm 2.48$ & $54.51^{\mathrm{aA}} \pm 0.16$ & $82.42^{\mathrm{aA}} \pm 8.08$ & $69.34^{\mathrm{bB}} \pm 1.47$ \\
\hline 7 & $55.92^{\mathrm{aA}} \pm 2.32$ & $55.90^{\mathrm{aA}} \pm 0.67$ & $87.71^{\mathrm{aA}} \pm 2.35$ & $66.10^{\mathrm{abB}} \pm 1.98$ \\
\hline 8 & $53.82^{\mathrm{aA}} \pm 1.59$ & $50.61^{\mathrm{bA}} \pm 0.31$ & $82.00^{\mathrm{aA}} \pm 1.10$ & $63.43^{\mathrm{aB}} \pm 1.98$ \\
\hline 11 & $57.47^{\mathrm{aA}} \pm 0.70$ & $52.25^{\mathrm{bA}} \pm 0.43$ & $83.31^{\mathrm{aA}} \pm 6.62$ & $64.77^{\mathrm{abB}} \pm 1.00$ \\
\hline
\end{tabular}

Means \pm standard deviation followed by different lowercase letters, in the column, are different at the $95 \%$ level of confidence. Means \pm standard deviation followed by different uppercase letters, in the lines and for the same property, are different at the $95 \%$ level of confidence.

In all $\mathrm{pH}$ conditions studied, to porcine plasma, the values of emulsifying activity did not differ statistically $(\mathrm{p}>0.05)$ to $\mathrm{pH} 3,5,7,8$ and 11 . These results proved satisfactory when compared with the results obtained by Chabanon et al. (2007), where crude globulin samples from canola reached $18 \%$ of emulsifying activity in $\mathrm{pH} 4.5$.

The values of emulsifying activity for hemoglobin were similar to values obtained for plasma. The values obtained for $\mathrm{pH} 3, \mathrm{pH} 5$ and $\mathrm{pH} 7$ did not differ statistically ( $\mathrm{p}>0.05$ ), but differed from the values obtained for the $\mathrm{pH} 8$ and $\mathrm{pH} 11$, equal among themselves.

The values of emulsion stability to the plasma was higher in all $\mathrm{pH}$ values tested and all means of emulsion stability are equal statistically $(\mathrm{p}>0.05)$ by Tukey test. For hemoglobin, the $\mathrm{pH}$ values tested influenced in the emulsion stability. In the $\mathrm{pH} 3$ there was obtained the lowest value of emulsion stability statistically different $(\mathrm{p}<0.05)$ than the others. To $\mathrm{pH} 5$, the emulsion stability was $69.34 \%$, a result statistically equal to values found for $\mathrm{pH} 7$ and 11 . When in $\mathrm{pH} 8$, the value obtained was $63.43 \%$ statistically equal to the values obtained at $\mathrm{pH} 7$ and 11 , statistically different $(\mathrm{p}<0.05)$ from the value obtained at $\mathrm{pH} 5$.

\subsection{Surface properties of porcine plasma and hemoglobin in different concentration values}

After obtaining the values of surface properties at different $\mathrm{pH}$ values, were tested different concentration values of plasma and hemoglobin and determine the same properties, with the $\mathrm{pH}$ set at 3 .

In Figure 3 are shown the profiles of the foaming capacity and foam stability for plasma and hemoglobin values for at different concentrations ( $\mathrm{pH} 3)$. 
Figure 3- Profiles of the Foaming capacity (a) and Foam Stability (b) at different concentrations for plasma (-a) and hemoglobin $(-\infty)$

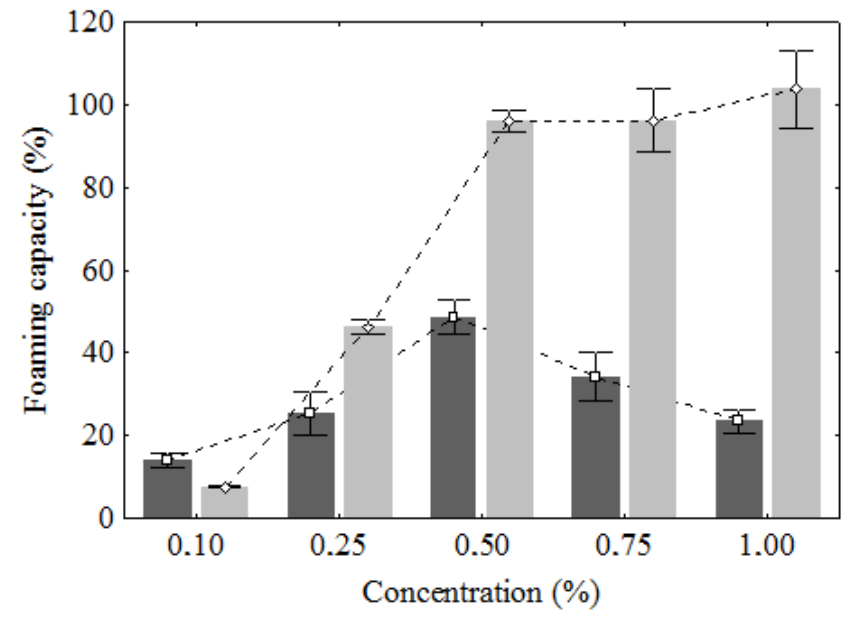

(a)

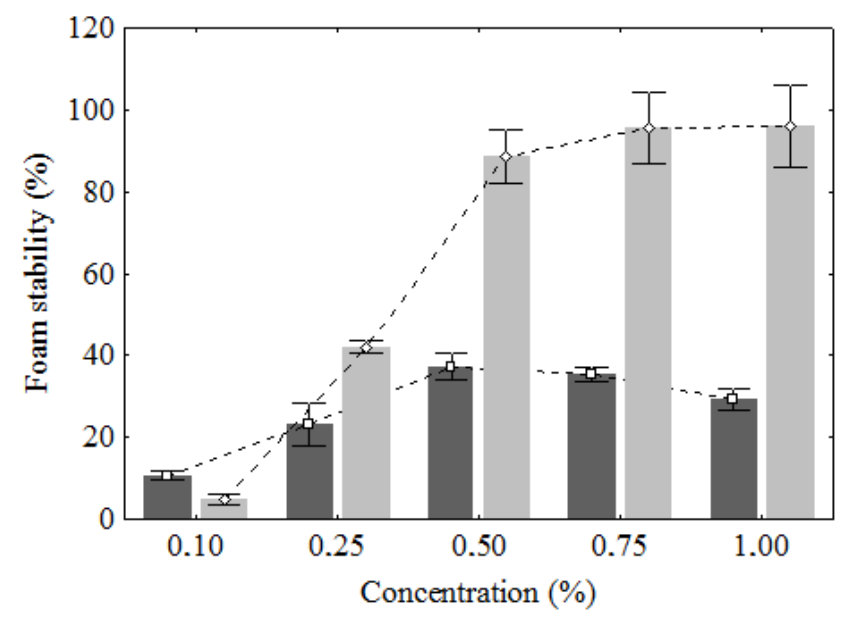

(b)

It can be seen in figure 3 the profiles of foaming capacity and foam stability were similar to the plasma and hemoglobin. For plasma, an increase in foaming capacity to the $0.5 \%$ concentration, decreasing the value of this property with increasing concentration. For hemoglobin, the concentration led to increased foaming capacity, this remains constant with increasing concentration.

Table 3 shows the mean of the results, the standard deviation and the Tukey test for the foaming capacity and foam stability of plasma and hemoglobin at different concentration values.

Table 3- Mean of the results, the standard deviation and the Tukey test for the foaming capacity ad foam stability of plasma and hemoglobin at different concentration values

\begin{tabular}{ccc|cc}
\hline $\begin{array}{c}\text { Concentration } \\
(\%, w / v)\end{array}$ & Plasma & Hemoglobin & Plasma & Hemoglobin \\
\hline 0.10 & $13.92^{\mathrm{aA}} \pm 1.57$ & $7.50^{\mathrm{aB}} \pm 0.15$ & $10.62^{\mathrm{aA}} \pm 0.88$ & $4.78^{\mathrm{aB}} \pm 1.00$ \\
0.25 & $25.30^{\mathrm{abA}} \pm 3.95$ & $46.30^{\mathrm{bB}} \pm 1.55$ & $23.08^{\mathrm{bA}} \pm 3.92$ & $41.93^{\mathrm{bB}} \pm 1.24$ \\
0.50 & $48.73^{\mathrm{cA}} \pm 2.94$ & $96.06^{\mathrm{cB}} \pm 1.79$ & $37.18^{\mathrm{cA}} \pm 2.65$ & $88.67^{\mathrm{cB}} \pm 5.32$ \\
0.75 & $33.98^{\mathrm{bA}} \pm 4.62$ & $96.29^{\mathrm{cB}} \pm 6.20$ & $35.15^{\mathrm{cA}} \pm 1.41$ & $95.61^{\mathrm{cB}} \pm 7.10$ \\
1.00 & $23.47^{\mathrm{abA}} \pm 2.13$ & $103.77^{\mathrm{cB}} \pm 7.29$ & $29.28^{\mathrm{bcA}} \pm 2.04$ & $96.15^{\mathrm{cB}} \pm 8.19$
\end{tabular}

Means \pm standard deviation followed by different lowercase letters, in the column, are different at the $95 \%$ level of confidence. Means \pm standard deviation followed by different uppercase letters, in the lines and for the same property, are different at the $95 \%$ level of confidence.

It is observed for the plasma, the higher foaming capacity was obtained by using the concentration of $0.50 \%$ and was also statistically different $(\mathrm{p}<0.05)$ of others results. For the 
concentration of $0.25 \%$, the value of the foaming capacity was $25.30 \%$, equal statistically by Tukey test, of results found for the concentrations of $0.10 \%$ and $1.00 \%$. The data show that with varying the concentration of plasma above $0.50 \%$ causes an excess of protein in the solution, resulting in a reduction in the amount of foam formed.

For hemoglobin, it was found that the concentrations of $0.50 \%, 0.75 \%$ and $1.00 \%$ had the highest values of foaming capacity. For lowest concentrations, the foaming capacity values obtained were low, values which are different from each other $(\mathrm{p}<0.05)$ by Tukey test. While there is an increase in the absolute value of the mean of foaming capacity from concentration of $0.50 \%$, these values remain within the same confidence interval (are statistically equal). This behavior makes possible a greater incorporation of protein in a food matrix without affecting this surface property.

The behavior displayed in foaming capacity by the plasma and hemoglobin in concentrations above $0.50 \%$ can be explained by the increased shear stress on the foam due to the increased mass of the diluted sample (DAMODARAM et al., 2010).

For the results of foam stability (Table 3) for the plasma and hemoglobin, it is found that the behavior for the foam stability was similar to the behavior exhibited in foaming capacity. If the sample concentration decreased to $0.1 \%$ and $0.25 \%$, there is a reduction in foam stability for the samples containing plasma and hemoglobin. For hemoglobin, the values of the foam stability for concentrations of $0.10 \%$ and $0.25 \%$ are statistically different results for each other $(\mathrm{p}<0.05)$. These values can be explained by the low concentration of protein in the samples. Liu et al. (2010) obtained $10 \%$ of the foam stability when utilized porcine plasma in concentration of $0.5 \%$ and at $\mathrm{pH}$ 5 , a value similar to that found in the present study for the sample with $0.1 \%$ plasma at $\mathrm{pH} 3$. The foam stability is also increased by large protein concentrations, since this increases the viscosity and facilitates the formation of a cohesive multilayer protein film at the interface (FENNEMA, 2000).

Once the sample concentration was higher than $0.50 \%$, the plasma showed equal results statistically ( $>0.05)$. The hemoglobin showed statistically equal results. These results indicate that, for the maximum stability of the foam formed using plasma or hemoglobin, the ideal concentration is near $0.50 \%$. The plasma, when studied by Liu et al. (2010), had the same pattern in these conditions, reaching values slightly above the $35 \%$.

In Figure 4 are shown the profiles of the emulsifying activity and emulsion stability for plasma and hemoglobin values for at different concentrations ( $\mathrm{pH} 3)$.

Both for the plasma as for hemoglobin, from concentrations of $1.5 \%$, the values were similar for emulsifying activity. The emulsion becomes effective when the sample concentration in the solution is equal or higher than $1.5 \%$ this condition protein shows superior results to those found by Prentice-Hernández et al. (2009) that, for samples of protein hydrolysates of cabrinha, reached $48.2 \%$ of maximum emulsifying activity. For the plasma, there has been a profile of increase in the 
emulsion stability to concentration of $3.5 \%$. The values obtained for the emulsion stability when utilized the hemoglobin presented a discreet profile of increase, with the value obtained for the concentration of $0.5 \%$.

Figure 4- Profiles of the Emulsifying Activity (a) and Emulsion Stability (b) at b) at different concentrations for plasma (-a.-) and hemoglobin $(-\infty)$

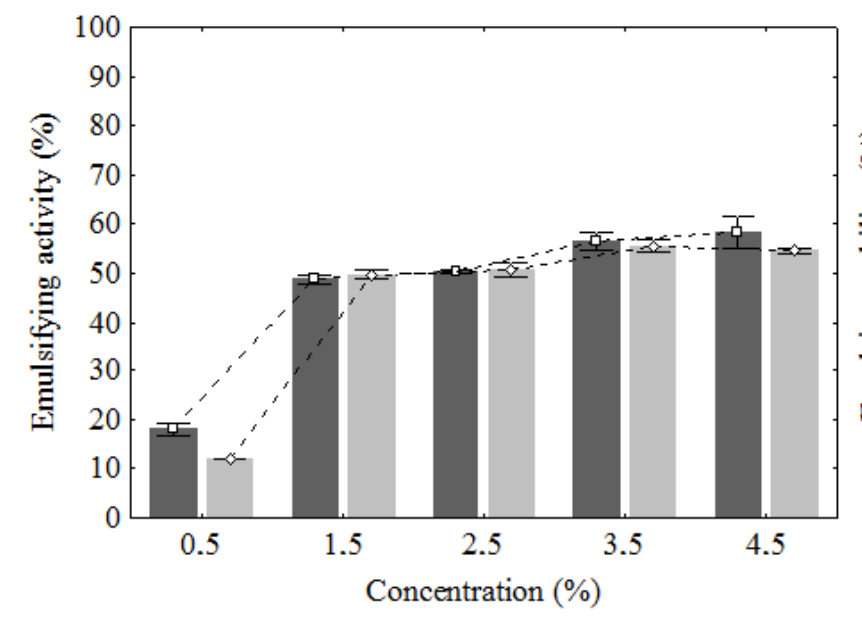

(a)

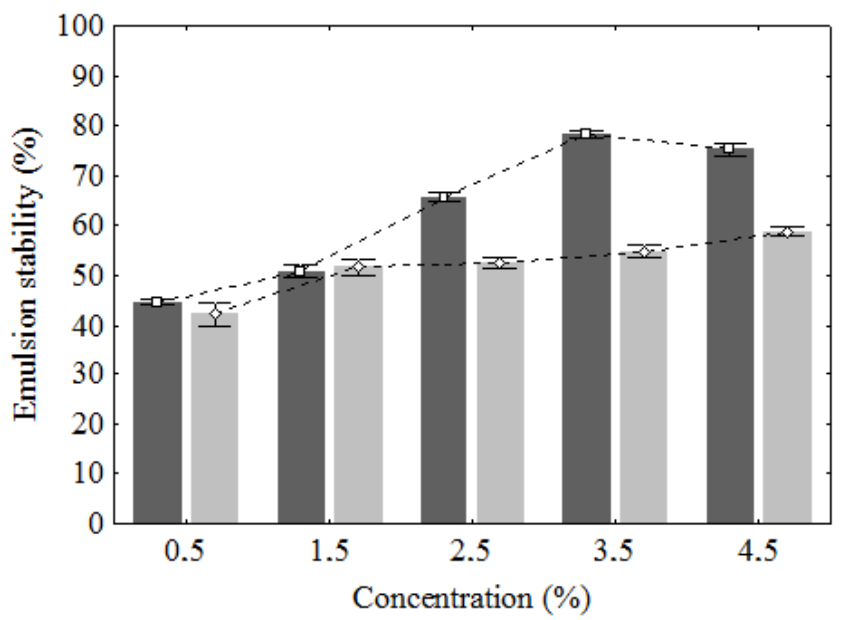

(b)

The results show the improved emulsion stability in the samples with increasing concentration up to $3.5 \%$. From that concentration, no significant decrease in emulsion stability, which shows a possible lack or excess protein, is the oil phase to form the emulsion. Hmidet et al. (2011) obtained similar results by studying Lula hydrolyzed protein at a concentration of $7.3 \%$, obtaining approximately $80 \%$ of emulsion stability.

Table 4 shows the mean of the results, the standard deviation and the Tukey test for the emulsifying activity and emulsion stability of plasma and hemoglobin at different concentration values.

Statistically, the values of emulsifying activity obtained using plasma and hemoglobin at concentrations of $1.5 \%$ and $2.5 \%$ were statistically equal to each other and different from the values obtained for $3.5 \%$ to $4.5 \%$, the latter being equal each other. It can be observed that even with a considerable variation of the concentrations, the samples were very minor variations in activity.

For the plasma, the results of all tested concentrations showed significant differences, with the lowest value obtained for the sample of lower concentration $(0.5 \%)$ with increased of emulsion stability to concentrations of $1.5 \%, 2.5 \%$ and $3.5 \%$. For the concentration of $4.5 \%$, the emulsion stability shows a decrease with a value of $75.24 \%$. 
Table 4: Mean of the results, the standard deviation and the Tukey test for the emulsifying activity and emulsion stability of plasma and hemoglobin at different concentration values.

\begin{tabular}{|c|c|c|c|c|}
\hline \multirow{2}{*}{$\begin{array}{c}\text { Concentration } \\
(\%, \mathrm{w} / \mathrm{v})\end{array}$} & \multicolumn{2}{|c|}{ Emulsifying activity (\%) } & \multicolumn{2}{|c|}{ Emulsion stability (\%) } \\
\hline & Plasma & Hemoglobin & Plasma & Hemoglobin \\
\hline 0.5 & $18.10^{\mathrm{aA}} \pm 1.03$ & $12.11^{\mathrm{aB}} \pm 0.01$ & $44.75^{\mathrm{aA}} \pm 0.35$ & $42.29^{\mathrm{aA}} \pm 1.83$ \\
\hline 1.5 & $48.85^{\mathrm{bA}} \pm 0.61$ & $49.80^{\mathrm{bA}} \pm 0.74$ & $50.91^{\mathrm{bA}} \pm 1.00$ & $51.73^{\mathrm{bA}} \pm 1.37$ \\
\hline 2.5 & $50.38^{\mathrm{bA}} \pm 0.22$ & $50.68^{\mathrm{bA}} \pm 1.03$ & $65.72^{\mathrm{cA}} \pm 0.59$ & $52.62^{\mathrm{bB}} \pm 0.77$ \\
\hline 3.5 & $56.48^{\mathrm{cA}} \pm 1.44$ & $55.56^{\mathrm{cA}} \pm 0.95$ & $78.27^{\mathrm{e}} \pm 0.48$ & $54.91^{\mathrm{bcB}} \pm 0.99$ \\
\hline 4.5 & $58.39^{\mathrm{cA}} \pm 2.73$ & $54.57^{\mathrm{cA}} \pm 0.31$ & $75.24^{\mathrm{dA}} \pm 0.92$ & $58.74^{\mathrm{cB}} \pm 0.71$ \\
\hline
\end{tabular}

Means \pm standard deviation followed by different lowercase letters, in the column, are different at the $95 \%$ level of confidence. Means \pm standard deviation followed by different uppercase letters, in the lines and for the same property, are different at the $95 \%$ level of confidence.

The value obtained for $4.5 \%$, using hemoglobin, was statistically equal ( $\mathrm{p}>0.05)$ to the value of $3.5 \%$ and different from others. Experiments with hemoglobin present a slight increase in the emulsion stability with increasing the concentration of protein, demonstrating a tendency of continuity.

\section{Conclusion}

Was observed that the behavior of the two proteins differ in the form of interaction with the same means the hemoglobin shows a higher availability at create stronger bonds forming colloids with higher volume and more stable. At $\mathrm{pH} \mathrm{3,} \mathrm{were} \mathrm{obtained} \mathrm{the} \mathrm{highest} \mathrm{values} \mathrm{of} \mathrm{foaming}$ capacity, which was also more stable in this condition. Both the foaming capacity as the foam stability was higher in concentration of $0.5 \%(\mathrm{w} / \mathrm{v})$. The variation of $\mathrm{pH}$ did not influence the emulsifying activity and emulsion stability when the plasma used as emulsifying agent. At $\mathrm{pH} 3$, the best concentration of plasma for emulsifying activity was $3.5 \%(\mathrm{w} / \mathrm{v})$, and with the increased concentration led to a decrease in emulsion stability. The hemoglobin showed better conditions for emulsifying activity at $\mathrm{pH}$, occurring differentiation only in emulsion stability, the results showed no significant difference between $\mathrm{pH} 3$ and 5. At $\mathrm{pH} 3$ the better results for the emulsifying activity using the hemoglobin were with concentration of $3.5 \%(\mathrm{w} / \mathrm{v})$ or higher.

\section{Acknowledgment}

The Research Initiation Program (Programa de Iniciação a Pesquisa - PIPES) of the State University of Santa Catarina (Universidade do Estado de Santa Catarina) for providing a research fellowship. 


\section{Resumo}

O presente estudo teve como objetivo avaliar as propriedades de superfície de plasma e hemoglobina em diferentes pHs e concentrações. As duas amostras testadas apresentaram perfis semelhantes da capacidade de formação de espuma na faixa de $\mathrm{pH}$ testada (3, 5, 7, 8 e 11), mas com valores diferentes e distantes da neutralidade. O plasma mostrou a capacidade de formação de espuma e estabilidade da espuma inferior para todos os valores de $\mathrm{pH}$. Os valores de estabilidade da emulsão foram maiores para o plasma em todos os $\mathrm{pHs}$, apresentando valores estatisticamente iguais. Para o plasma, a capacidade de formação de espuma foi superior para a concentração de $0,50 \%$, e estatisticamente diferente das demais concentrações. A diminuição da concentração de $0,50 \%$ para $0,1 \%$ e $0,25 \%$, provocou uma redução na estabilidade da espuma tanto para o plasma como para a hemoglobina. Para as duas amostras, a partir da concentração de $1,5 \%$, os valores de atividade emulsificante foram semelhantes. Os valores obtidos nas concentrações de 1,5\% e 2,5\% foram estatisticamente iguais entre si e diferentes dos valores obtidos para 3,5 e 4,5\%. A emulsão formada utilizando plasma e hemoglobina foi mais estável a partir da concentração de 3,5\% e 1,5\%, respectivamente. Em relação às propriedades da superfície, as proteínas mostraram-se promissoras para o uso em alimentos.

\section{References}

AVRAMENKO, N. A.; LOW, N. H.; NICKERSON, M. T. The effects of limited enzymatic hydrolysis on the physicochemical and emulsifying properties of a lentil protein isolate. Food Research International, v.51, n.1, p. 162$169,2013$.

CHABANON, G.; CHENU, S.; CHEVALOT, I.; FRAMBOISIER, X.; MARC I. Hydrolysis of rapeseed protein isolates: Kinetics, characterization and functional properties of hydrolysates. Process Biochemistry. v.42, n.10, p1419-1428, 2007.

DAMODARAM, S.; FENNEMA, O. R.; KIRK, L. P. Química de alimentos de Fennema. Artmed, Porto Alegre, 900p, 2010.

FENNEMA, O. Química de los Alimentos. 2a ed. Zaragoza, Acribia, 2000.

FOEGEDING, E.A.; LUCK, P.J.; DAVIS, J.P. Factors determining the physical properties of protein foams. Food Hydrocolloids, v.20, n.2-3, p-284-292, 2006.

HMIDET, N.; BALTI, R.; NASRI, R.; SILA, A.; BOUGATEF, A.; NASRI, M. Improvement of functional properties and antioxidant activities of cuttlefish muscle proteins hydrolized by Bacillus mojavensis A21 proteases. Food Research International. v.44, n.9, p-2703-2711, 2011.

JAMDAR, S. N.; RAJALAKSHMI, V.; PEDNEKAR, M. D.; JUAN F.; Yardi, V.; SHARMA, A. Influence of degree of hydrolysis on functional properties, antioxidant activity and ACE inhibitory activity of peanut protein hydrolysate. Food Chemistry. v. 121, n.1, p- 178-184, 2010.

LIU, Q.; KONG, B.; XIONG, Y. L.; XIA, X. Antioxidant activity and functional properties of porcine plasma protein hydrolysate as influenced by the degree of hydrolysis. Food Chemistry, v.118, n.2, p-403-410, 2010.

ORDÓÑEZ, J.A. Tecnologia de Alimentos. $1^{\text {a }}$ ed. Porto Alegre, Artmed, 2005.

PRENTICE-HERNÁNDEZ, C.; SALAS-MELLADO, M.; SILVA, C. M.; ZAVARZE, E.R. Functionality of bluewing searobin (Prionotus punctatus) protein hydrolysates obtained from different microbial proteases. Química Nova, v.32, n.7, p-1739-1743, 2009.

SILVA, M. H. L. Desenvolvimento e caracterização de um isolado protéico de soja modificado com perfil de solubilidade da caseína do leite humano. Viçosa, Brasil: Universidade Federal de Viçosa, PhD thesis, 2007.

STATSOFT Inc., Tulsa, OK 
WANG, J.C.; KINSELLA, J. E. Functional properties of novel proteins: alfafa leaf protein. Journal of Food Science, v.41, n.2, p-286-292, 1976.

YU, Y.; HU, B.; MIYAGUCHI, Y.; BAI, X.; DU Y.; LIN B. Isolation and characterization of angiotensin I-converting enzyme inhibitory peptides derived from porcine hemoglobina. Peptides, v.27, n.2, p-2950-2956, 2006. 